\title{
Implement the ECFA: \\ Prospects of a Bilateral Investment Agreement between Mainland China and Taiwan
}

\author{
Jie Huang
}

\begin{abstract}
Between Mainland China and Taiwan, ${ }^{1}$ the political dispute over sovereignty is a deeply contentious issue. ${ }^{2}$ For years, much scholarship has discussed how to maintain peace between the Taiwan Strait from the political and military aspects. ${ }^{3}$ These efforts are valuable because the political controversies and economic instability had shrouded the Strait for decades since 1949. The situation begun to change since Mr. Ma Yingjeou of the Kuomintang (hereinafter "KMT") took the president's office in Taiwan in 2008. He engineered a dramatic turnaround in crossstrait relations. ${ }^{4}$ By accepting the Ninety-two Consensus [Jiuer Gongshi], he significantly reduced tension with Mainland China. He also moved the cross-strait economy from the nongovernmental informal level to the formally cooperative governmental level, and from sporadic to regular and comprehensive. For example, Taiwan and Mainland China concluded the Economic Cooperative Framework Agreement (hereinafter "ECFA") on April 26, 2009. The ECFA laid down a milestone for cross-strait bilateral cooperation in trade, service, and investment.
\end{abstract}

In close race of 2012 Taiwan presidential election, Ma won 51.5 per cent of the final tally, beating opposition candidate Tsai Ing-wen of Taiwan Democratic Progressive Party (hereinafter "DPP"), who had 45.6 per cent. Addressing supporters, Ma stated that "You have told me, in the clearest voice possible, to continue on my current path." Ma's continuation of Mainlandfriendly policy is also highly welcomed by Washington and Beijing. 6 Therefore, implementing

\footnotetext{
Associate Professor of Law at Shanghai Institute of Foreign Trade School of Law in China. Director of China Association of Private International Law. Duke S.J.D. (2010). This paper was made possible in part through the International Trade Law Project of Shanghai Education Commission (J51204) and through Shanghai Pujiang Rencai Program (2011-2014). The author can be reached at humilityus@gmail.com. All comments are highly appreciated.

1 "Taiwan," including Taiwan Island, the Pescadores Islands (or Penghu), and the islands of Matsu and Kinmen, are under the effective jurisdiction of the government in Taipei.

${ }^{2}$ See generally MA YinG-JEOU wins TAIWAN ELECTION 109-22, http://www.ft.com/cms/s/0/7e4b45bc-3eb3-11e1-913900144feab49a.html\#axzz1k1421RBy (last visited Jan 25, 2010). Robert S. Ross, Taiwan's Fading Independence Movement, 85 141, 141-48 (2006) Fisi Wang, China's Search for a Grand Strategy, 90 68, 68-79 (2011) For US policy on the cross-strait sovereignty issue, see Relations with the People on Taiwan, 18 I.L.M. 275 1979; Taiwan Relations Act, 18 I.L.M. 873 1979.

${ }^{3}$ Eg., Richard C. Bush, Untying the Knot: Making Peace in the Taiwan Strait (Brookings Institution Press 2005).

${ }^{4}$ MA YiNG-JEOU WINS TAIWAN ELECTION, http://www.ft.com/cms/s/0/7e4b45bc-3eb3-11e1-913900144feab49a.html\#axzz1k1421RBy (last visited Jan 25, 2012).

${ }^{5}$ Id.

${ }^{6}$ Congratulating Ma's re-election, the White House stated that "Cross-Strait peace, stability and improved relations, in an environment free from intimidation, are of profound importance to the United States. We hope the impressive efforts that both sides have undertaken in recent years to build cross-Strait ties continue." MA YING-JEOU, TAIWANESE PRESIDENT, WINS REELECTION IN ClOSE RACE, http://www.huffingtonpost.com/2012/01/14/ma-ying-jeou-taiwanese-president-wins-reelection_n_1206222.html. (Last visited Jan 25, 2012).
} 
the ECFA will be important for Ma, particularly to satisfy his "life-saving"" entrepreneur electorates who have heavy investment in Mainland China. ${ }^{8}$

However, few efforts have been devoted to analysing how to implement the ECFA. ${ }^{9}$ Among little valuable scholarship, more attention has been paid to cross-strait trade than investment. Nevertheless, concluding a Bilateral Investment Agreement (hereinafter "BIA") will be of top priority for Ma's cross-strait agenda, because at least three rounds of negotiation with Mainland China was held in Ma's first term but no laudable result. Moreover, some have complained of not enough progress in attracting Chinese investment to Taiwan. ${ }^{10}$ Cross-strait investment is an important and prosperous field in practice, but has not been fully explored in literature thus far. This Article aims to fill this gap. It focuses on the practice and regulation of cross-strait investment and discusses the prospects of an Investment Agreement under the ECFA.

This Article can be divided into four parts. The first part uses statistics to demonstrate the growing cross-strait investment and incompetent contemporary investment protection mechanisms in Mainland China and Taiwan. It argues that a Bilateral Investment Agreement (hereinafter "BIA") can best boost investors' confidence. It surveys the three rounds of negotiations that have been conducted between Mainland China and Taiwan. It concludes that macro and micro challenges should be resolved for a successful cross-strait BIA. The second part concentrates on three macro challenges of the BIA: politic disputes between Mainland China and Taiwan, disagreements between KMT and DPP, and different focuses of investment between Mainland China and Taiwan. It provides solutions to each challenge. Micro challenges against a successful BIA come from differences in Mainland China and Taiwan laws. Therefore, the third part analyzes the similarities and differences of laws in Mainland China and Taiwan. It also compares the investment protection agreements concluded by Mainland China and Taiwan with other countries respectively. It argues that Mainland China and Taiwan can possibility reach agreements upon major provisions of the BIA such as the definitions of investors and investment, National Treatment, Most-Favored-Nation Treatment (hereinafter "MFN Treatment"), security exception, investment protection, and dispute resolution. Regarding the negotiation strategy, it suggests that, at the current stage, due to political disputes and partisan in Taiwan, the BIA will be a framework only. The ARATS-SEF meeting ${ }^{11}$ or the Cross-Strait Economic Cooperation Committee will play a significant role in developing the framework. New consensus can be added to the framework as amendments. The forth part discusses the BIA and the cross-strait political prospects. It argues that cautions should be put when applying neofunctionalism,

\footnotetext{
${ }^{7}$ Business BaCKs Ma in TAiWAN ELECTIONS Business BaCKS Ma in TAIWAN ELECTIONS, http://www.ft.com/intl/cms/s/0/e37924ee-3b6c-11e1-bb39-00144feabdc0.html\#axzz1kzi3a5sC (last visited Jan 31, 2012) (last visited Jan 28, 2012).

${ }^{8}$ Andrew Jacobs, Ma Ying-jeou Is Re-elected as Taiwan's President, The New York Times, Jan. 14, 2012, http://www.nytimes.com/2012/01/15/world/asia/taiwan-presidential-election.html (last visited Jan 28, 2012)

${ }^{9}$ For an English version, see www.mac.gov.tw/public/data/051116322071.pdf, last visited Dec 4, 2011. For historical background of the ECFA, see Chi-An Chou, A Two-Edged Sword: The Economic Cooperation Framework Agreement between the Republic of China and the People's Republic of China, 6 InT'L L. \& MGMT. Rev. 1, 2 (2009); Cho-Hsin Su, Reminiscent of Zollverein-The ECFA from a Constructivist View, 27 CHINESE (TAIWAN) Y.B. INT'L L. \& AFF. 149, 149-63 (2009). For comments of the ECFA, see Yen-Hsueh Lai, Interpreting the ECFA: A New Common Market for Taiwan and Mainland China?, 4 J. E. ASIA \& INT'L L. 173, 173-91 (2011); Liang Zhang, Unprecedented RTA Practices between the Customs Territories of China, 4 J. E. ASIA \& INT'L L. 81, 81-104 (2011).

${ }^{10}$ See supra note 4.

${ }^{11}$ ARATS refers to the Association for Relations across the Taiwan Straits; SEF refers to the Straits Exchange Foundation. For more information of ARATS, see http://www.arats.com.cn/. For more information of SEF, see http://www.sef.org.tw/.
} 
intergovernmentalism, and liberal intergovernmentalism to the cross-strait situation. It is hard to predict whether the BIA will promote political integration between Mainland China and Taiwan in the near future. However, it will certainly help bring stability and prosperity to the people of the Taiwan Strait. Peace and development are the hope of the people and should be the goal of the governments.

\section{Cross-strait Investment: Current Practice and Law}

\section{Growing Cross-Strait Investment}

Soon after Mainland China adopted the opening-up policy in 1978, it tried to start crossstrait economic exchanges with Taiwan. On New Year's Day of 1979, the Standing Committee of the National People's Congress (hereinafter "NPC") of the People's Republic of China (hereinafter "PRC") issued a Message to Compatriots in Taiwan. This Message initiated a proposal for "developing trade, supplying each other's needs, and conducting economic exchanges."12 Since then, Mainland China has provided Taiwan businesspersons with preferential treatments such as tax exemption or reduction. ${ }^{13}$ In 1988, the Mainland State Council issued the Regulations for Encouraging Investment by Taiwan Compatriots. In 1994, the Law on the Protection of Investment by Compatriots from Taiwan was published and its implementation regulation was formulated in 1999. These laws aim to encourage Taiwan compatriots to invest in Mainland China and to promote cross-strait economic development. ${ }^{14}$ Enterprises established by Taiwan investment can also enjoy favorable terms according to relevant regulations of the Mainland State Council. ${ }^{15}$ Local governments also enacted regulations and made efforts to improve investment environment so as to encourage and protect Taiwan investors. Since 1993, Taiwan business people have considered Mainland China as their first choice for outside-the-island investment. ${ }^{16}$ From 1991 to 2008, Taiwan businesspersons' investment in Mainland China takes $57.13 \%$ of its outside-the-island investment. ${ }^{17}$ The following chart indicated that Taiwan investment in Mainland China has kept increasing since 1991. In 2009 and 2010, Taiwan investment took 5.2\% and 5\%, respectively, of the total foreign investment in Mainland China. ${ }^{18}$

\section{Statistics on Taiwan Investment in Mainland China ${ }^{19}$}

Unit: US\$1,000

\section{Investment In Mainland China}

\footnotetext{
${ }^{12}$ China's Policy on "Three Direct Links" Across the Taiwan Straits, promulgated by Information Office of the State Council of the People's Republic of China, and effective on December 1, 2003.

${ }^{13}$ Id.

${ }^{14}$ Art. 1 of Law for Protecting Taiwan Compatriots' Investment, enacted by the Sixth Meeting of the Standing Committee of the Eighth National People's Congress on March 5, 1994.

${ }^{15} \mathrm{Id}$., art. 13.

${ }^{16}$ China's Policy on "Three Direct Links" Across the Taiwan Straits, promulgated by Information Office of the State Council of the People's Republic of China, and effective on December 1, 2003.

${ }^{17}$ Hongming Cai, Lianan Jingji Hezuo Jiagou Xieyi Zhongdian Yanxi [Concentrated Study of Cross-strait Economic Cooperation Framwork], 11 MaOYi ZhengChe LunTAN [JouRnal of TRADE PoliCy] 16.

${ }_{18}^{18}$ http://www.mofcom.gov.cn/diaoca/2/dyncolumn.html, (last visited Jan 28, 2012)

19 Sources: statistics from www.tnst.org.tw/ezcatfiles/cust/img/img/3-02.xls, (last visited Jan 28, 2012)
} 


\begin{tabular}{|ccc|}
\hline Year & $\begin{array}{c}\text { Number of } \\
\text { Project }\end{array}$ & Amount \\
\hline $\mathbf{1 9 9 1 - 1 9 9 8}$ & 21,646 & $13,242,658$ \\
\hline $\mathbf{1 9 9 9}$ & 488 & $1,252,780$ \\
\hline $\mathbf{2 0 0 0}$ & 840 & $2,607,142$ \\
\hline $\mathbf{2 0 0 1}$ & 1,186 & $2,784,147$ \\
\hline $\mathbf{2 0 0 2}$ & 1,626 & $2,864,301$ \\
\hline $\mathbf{2 0 0 3}$ & 2,038 & $3,103,799$ \\
\hline $\mathbf{2 0 0 4}$ & 2,004 & $6,940,663$ \\
\hline $\mathbf{2 0 0 5}$ & 1,297 & $6,006,953$ \\
\hline $\mathbf{2 0 0 6}$ & 1,090 & $7,642,335$ \\
\hline $\mathbf{2 0 0 7}$ & 996 & $9,970,545$ \\
\hline $\mathbf{2 0 0 8}$ & 482 & $9,843,355$ \\
\hline $\mathbf{2 0 0 9}$ & 590 & $7,142,593$ \\
\hline $\mathbf{2 0 1 0}$ & 518 & $12,230,146$ \\
\hline Total & $\mathbf{3 4 , 8 0 1}$ & $\mathbf{8 5 , 6 3 1 , 4 1 7}$ \\
\hline
\end{tabular}

Although since 1978 Taiwan investment has prospered in Mainland China, capital from Mainland China had been largely blocked from Taiwan. Mainland enterprises were not allowed to invest or to set up business agencies in Taiwan. Mainland's business people faced many restrictions on business tours to Taiwan. After its WTO accession, Taiwan began to move away from this restrictive policy. In 2002, Taiwan opened 58 service sectors to Mainland China, taking $50 \%$ of its WTO obligations. ${ }^{20}$ However, little Mainland capital entered Taiwan market because the opened sectors are either not in popular demand, or have already been highly competitive and not profitable. ${ }^{21}$

Until 2008, Mr. Ma Yingjeou of the KMT won the presidential election in Taiwan and adopted an active welcoming attitude to Mainland capital. On April 30, 2009, Taiwan published Regulation for Mainland Investors to Invest in Securities and Futures in Taiwan. On June 30 of the same year, Taiwan issued Regulation of Permitting Mainland People to Invest in Taiwan (hereinafter "Taiwan Regulation of Mainland Investment") and Regulation of Permitting Mainland Enterprises to Establish Branches or Representative Offices in Taiwan. Accordingly, Mainland capital is permitted to invest in securities, futures, and enterprises in Taiwan. Mainland nature persons, legal persons, associations, or other institutes are also allowed to directly invest in Taiwan; or they can establish an enterprise in a third region and the enterprise is also permitted to invest in Taiwan. ${ }^{22}$ Mainland investors can hold Taiwan companies' share, establish subsidiaries and branches, or run wholly owned or joint ventures in Taiwan. ${ }^{23}$ In 2010, Mainland

\footnotetext{
${ }^{20}$ The Progress of Taiwan Permits Mainland Enterprises to Invest in Taiwan, in INTERPRETATION OF INVESTMENT LAWS ON Mainland ENTERPRises INVESTING In TAIWAN AREA 203-08.

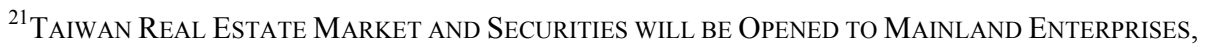
http://www.cs.com.cn/fc/02/200805/t20080506_1449856.htm (last visited Jan 2, 2012).

${ }^{22}$ Art. 2 of Regulation of Permitting Mainland People to Invest in Taiwan.

${ }^{23} I d$, at art. 4.
} 
China and Taiwan concluded the ECFA. It requires the two parties to establish an investment ${ }^{24}$ protection mechanism, increase transparency on investment-related regulations, gradually reduce restrictions on mutual investments, and promote investment facilitation. ${ }^{25}$ In November 2011 , Mainland China issued the Regulation of Mainland Enterprises Invest in Taiwan (hereinafter "Mainland Regulation of Investing in Taiwan"). This Regulation aims to implement the ECFA and serves as guidance for Mainland enterprises investing in Taiwan. Taiwan has also published the guidelines for attracting Mainland investment in manufacturing, ${ }^{26}$ service,${ }^{27}$ and public construction projects. Thus far, the manufacturing industry has opened 204 categories, ${ }^{28}$ the service industry opens 161 categories, ${ }^{29}$ and public construction opens 43 categories, ${ }^{30}$ to Mainland capital. The following table demonstrates that Mainland investors have responded warmly to Taiwan's opening measures. In Taiwan, banking, and computers manufacturing industries receive the majority of Mainland investment. ${ }^{31}$

\section{Statistics on Mainland Capital Invested in Taiwan ${ }^{32}$ (June, 2009-December, 2011) Unit: US\$1,000; \%}

\begin{tabular}{|c|c|c|c|c|c|c|c|c|c|c|c|c|}
\hline & \multicolumn{9}{|c|}{2009} & \multicolumn{9}{c|}{$\mathbf{2 0 1 0}$} \\
& No. & $\begin{array}{c}\text { Growth } \\
\text { Rate }\end{array}$ & Amount & $\%$ & No. & $\begin{array}{c}\text { Growth } \\
\text { Rate }\end{array}$ & Amount & $\%$ & No. & $\begin{array}{c}\text { Growth } \\
\text { Rate }\end{array}$ & Amount & $\%$ \\
\hline Jan & - & - & - & - & 10 & - & 30,468 & - & 10 & 0 & 5,011 & -84 \\
\hline Feb & - & - & - & - & 5 & - & 723 & - & 8 & 60 & 1,898 & 163 \\
\hline Mar & - & - & - & - & 1 & - & 262 & - & 10 & 900 & 6,921 & 2,542 \\
\hline Apr & - & - & - & - & 8 & - & 3,370 & - & 3 & -63 & 487 & -86 \\
\hline May & - & - & - & - & 5 & - & 4,828 & - & 14 & 180 & 5,369 & 11 \\
\hline Jun & - & - & - & - & 6 & - & 2,773 & - & 9 & 50 & 1,982 & -29 \\
\hline Jul & 7 & - & 380 & - & 12 & 71 & 28,589 & 7,423 & 10 & -17 & 7,495 & -74 \\
\hline Aug & 1 & - & 389 & - & 6 & 500 & 2,107 & 442 & 8 & 33 & 2,294 & 9 \\
\hline Sep & 2 & - & 441 & - & 10 & 100 & 14,264 & 3,134 & 8 & -20 & 3,614 & -75 \\
\hline Oct & 5 & - & 4,606 & - & 7 & 40 & 1,860 & -60 & 3 & -57 & 3,211 & 73 \\
\hline Nov & 0 & - & 0 & - & 6 & - & 4,695 & - & 15 & 150 & 4,508 & -4 \\
\hline
\end{tabular}

${ }^{24}$ Here, "investment" has a broad scope and is unnecessarily related to trade.

${ }^{25}$ Art. 5.2 of the ECFA. For comments of this provision, see Guiguo Wang, China's FTAs: Legal Characteristics and Implications, 105 AM. J. INT'L L 493, 512 (2011)

${ }^{26}$ The guidelines of opening manufacturing industry to Mainland capital is (1) negative list; (2) assist cross-strait industry cooperation and give priority to important bridging ${ }^{26}$ projects; (3) give priority to projects with a complete industry chain and competitive in the international market, and have manufacturing and management ability. "Bridging projects" are proposed by Taiwan Ministry of Economy to help companies expand their business to the other side by taking advantage of the cross-strait relationship built by governments.

${ }^{27}$ The guideline of opening service industry to Mainland capital is (1) give priority to wholesale and retail industries; (2) assist the cross-strait sea transportation and air transportation and open these two industries to Mainland people; (3) defer the opening of recognition of lawyers and accountants, or service industries that require engineer licenses.

${ }^{28}$ Taiwan Released the Third Phrase Projects Open for Mainland Investment, http://www.moea.gov.tw/Mns/populace/news/News.aspx?kind=1\&menu_id=40\&news_id=24832, last visited on March $24,2012$. ${ }^{29}$ Id.

${ }^{30} I d$. The guideline of opening public construction projects to Mainland capital is the Act to Promote Citizens to Participate in Public Construction.

${ }^{31}$ Page 5, Ping Zhu, Policy Explanation of Mainland Capital Investing in Taiwan available at

Http://iitw.cnfi.org.tw/download/c05-2.pdf. Ms. Zhu is the head of the Investment Approval Committee of Taiwan Ministry of Economy.

${ }^{32}$ Sources: Statistics on http://cdnet.stpi.org.tw/techroom/policy/2011/policy 11 049.htm, http://cdnet.stpi.org.tw/techroom/policy/2012/policy 12 009.htm, last visited March 28, 2012. Percentage is calculated by comparing with the same month in the previous year. 


\begin{tabular}{|c|c|c|c|c|c|c|c|c|c|c|c|}
\hline $\begin{array}{c}\text { Jan- } \\
\text { Dec }\end{array}$ & 23 & - & 37,486 & - & 79 & 243 & 94,345 & 152 & 102 & 29 & 43,736 \\
\hline
\end{tabular}

\author{
The Top Three Sectors Receiving Mainland Investment ${ }^{33}$ \\ (June, 2009-January, 2012) \\ Unit: US\$1,000; \%
}

\begin{tabular}{|c|c|c|c|}
\hline & Number & Amounts & Percentage \\
\hline Banking & 2 & 91,481 & 33.62 \\
\hline $\begin{array}{c}\text { Computer, } \\
\text { Electronic Products } \\
\text { and Optical } \\
\text { Products } \\
\text { Manufacturing }\end{array}$ & 12 & 56,383 & 20.72 \\
\hline Wholesale and Retail & 114 & 47,551 & 17.48 \\
\hline Information Service & 23 & 39,266 & 14.43 \\
\hline Conference Service & 9 & 10,657 & 3.92 \\
\hline
\end{tabular}

\title{
2. Incompetent Investment Protection Mechanism
}

With the growth of cross-strait investment, both Mainland and Taiwan investors express concerns regarding the security of their investment. Mainland laws for Taiwan investors are unclear in important legal concepts such as whether indirect expropriation and nationalization are included and how to compensate investors. ${ }^{34}$ In 2008, Taiwan Central Chamber of Commerce conducted a survey regarding Mainland China investment dispute mechanism among Taiwan businesspersons investing in Mainland China. According to this survey, in investment disputes, $42.24 \%$ of respondents felt hard to communicate with Mainland government agencies (including police offices, industry and commercial bureaus, and taxation bureaus); $90.35 \%$ thinks Mainland government's understanding of rule of law was weak; $76.94 \%$ believes Mainland government's ability to solve disputes depended on the types of disputes and the background of parties. ${ }^{35}$ This survey also demonstrates that Mainland government agencies and courts may interpret same laws differently and the law in practice may be different from the law in books. ${ }^{36}$ Moreover, Taiwan businesspersons are also concerned with compensation of nationalization, personal security, and labor disputes, among others, according to statistics by SEF.

\footnotetext{
${ }^{33}$ Sources: Statistics on http://cdnet.stpi.org.tw/techroom/policy/2012/policy 12 009.htm, last visited March 28, 2012.

${ }^{34}$ Xixian Song, Status Quo, Problems and Solutions of Legal Protection to Taiwan Investment, 3 China International Economic Law Annual Meeting Paper 208, 208-210 (2011).

${ }^{35}$ Taiwan Central Chamber of Commerce Published Survey Result of Mainland China Investment Dispute Mechanism, http://www.taiwanpage.com.tw/new_view.cfm?id=16955 (last visited Dec 20, 2011).

${ }^{36} \mathrm{Id}$.
} 
Business Disputes Solved with the Assistance of SEF ${ }^{37}$

\begin{tabular}{|c|c|c|c|c|}
\hline \multirow{2}{*}{$\begin{array}{l}\text { Type } \\
\text { Year }\end{array}$} & \multirow[b]{2}{*}{$\begin{array}{l}\text { Personal } \\
\text { Security }\end{array}$} & \multicolumn{2}{|c|}{ Property Rights and Interests } & \multirow[b]{2}{*}{ Tota } \\
\hline & & $\begin{array}{c}\text { Taiwan } \\
\text { Businessperson } \\
\text { Complaint }\end{array}$ & $\begin{array}{c}\text { Mainland } \\
\text { Businessperson } \\
\text { Complaint }\end{array}$ & \\
\hline 1991 & 0 & 13 & 0 & 13 \\
\hline 1992 & 2 & 23 & 0 & 25 \\
\hline 1993 & 17 & 57 & 4 & 78 \\
\hline 1994 & 30 & 40 & 4 & 74 \\
\hline 1995 & 41 & 43 & 14 & 98 \\
\hline 1996 & 36 & 25 & 9 & 70 \\
\hline 1997 & 35 & 22 & 13 & 70 \\
\hline 1998 & 64 & 48 & 15 & 127 \\
\hline 1999 & 58 & 35 & 3 & 96 \\
\hline 2000 & 51 & 31 & 1 & 83 \\
\hline 2001 & 67 & 36 & 1 & 104 \\
\hline 2002 & 91 & 43 & 1 & 135 \\
\hline 2003 & 107 & 32 & 3 & 142 \\
\hline 2004 & 124 & 27 & 3 & 154 \\
\hline 2005 & 133 & 54 & 5 & 192 \\
\hline 2006 & 197 & 85 & 8 & 290 \\
\hline 2007 & 249 & 42 & 0 & 291 \\
\hline 2008 & 312 & 221 & 9 & 542 \\
\hline 2009 & 353 & 428 & 15 & 796 \\
\hline 2010 & 328 & 368 & 5 & 701 \\
\hline 2011 & 274 & 328 & 4 & 606 \\
\hline Jan, 2012 & 23 & 32 & 0 & 55 \\
\hline
\end{tabular}

${ }^{37}$ Source: Statistics provided by SEF Economy and Trade Service Sector, made on March 8, 2012, at http://www.seftb.org/mhypage.exe?HYPAGE=/02/02 3.asp, (last visited March 20, 2012) 


\begin{tabular}{|c|c|c|c|c|}
\hline Feb, 2012 & 24 & 27 & 1 & 52 \\
\hline Total & $\mathbf{2 6 1 6}$ & $\mathbf{2 0 6 0}$ & $\mathbf{1 1 8}$ & $\mathbf{4 7 9 4}$ \\
\hline
\end{tabular}

Taiwan laws for Mainland investment are also still underdevelopment. For example, Taiwan Regulation of Mainland Investment does not indicate that Mainland investment will not be nationalized/expropriated. It is also silent regarding compensation on nationalization/expropriation. Moreover, the market entry requirements imposed upon Mainland capital are different from those for other foreign capital. ${ }^{38}$ Therefore, fewer industries are open to Mainland investment than to other foreign investment. Taiwan laws concerning Mainland investment does not indicate that Mainland capital can enjoy National Treatment and MFN Treatment. On the contrary, other foreign investments can enjoy National Treatment according to Taiwan Foreigner Investment Regulation and Regulation of Overseas Chinese Investing in Taiwan $;^{39}$ they also have MFN Treatment according to investment protection agreements concluded by Taiwan. ${ }^{40}$

Currently, no investment protection mechanism exists between Mainland China and Taiwan. Although TRIMs, GATS, and DSU of the WTO concern trade-related investment; however, they apply only between Mainland and Taiwan governments. In other words, a private investor has no standing in the DSB. Therefore, the WTO system cannot solve investment disputes between an investor and a host region in the cross-strait context. ICSID is also not an acceptable venue either, because Taiwan is not an ICSID member. Moreover, Mainland China accepts the ICSID ruling only when it consents to ICSID jurisdiction. Mainland China probably will not consent to ICSID jurisdiction over its disputes with a Taiwan investor. Therefore, the growing investment demands improvement of current cross-strait investment protection legal framework.

\section{BIA and Challenges}

A BIA between Mainland China and Taiwan will boost investors' confidence. Concluding a BIA is also in the ECFA agenda. ${ }^{41}$ The ECFA requires Mainland China and Taiwan to start consultations on investment within six months after its effective date. ${ }^{42}$ In June 2010, the fifth Chen-Jiang Meeting ${ }^{43}$ (ARATS-SEF meeting) agreed that negotiating a BIA should be an important agenda of future meetings. However, the negotiation did not go smoothly. In December 2010, the sixth Chen-Jiang Meeting discussed the BIA but achieved no successful result. In October 2011, the seventh Chen-Jiang Meeting also discussed the BIA, but the two sides still failed to reach an agreement. This is partially due to Taiwan presidential election. The election was on January 14, 2012 and the BIA was criticized by the apposing DPP as potentially

\footnotetext{
${ }^{38}$ See infra note 86 and accompanying texts.

${ }^{39}$ Art. 17 of Taiwan Regulation of Foreign Investment and Taiwan Regulation of Overseas Chinese Investment.

${ }^{40}$ Eg., Art. 3 of Taiwan-Panama Investment Protection Agreement, Art. 3 of Taiwan- Macedonia Investment Protection Agreement, Art. 5 of Taiwan- Salvador Investment Protection Agreement, Art. 3 of Taiwan- Burkina Faso Investment Protection Agreement, Art. 3 of Taiwan- Guatemala Investment Protection Agreement.

${ }^{41}$ Art. 5.2 of the ECFA.

${ }^{42} \mathrm{Id}$, at art. 5.

${ }^{43}$ Chen is the head of ARATS. Jiang is the head of SEF.
} 
making Taiwan lose economic independence. Therefore, Ma hesitated to conclude a BIA with Mainland China before the election.

Therefore, in Ma's first term, three rounds of BIA negotiation were conducted but no agreement was concluded yet. In his second term, Ma will continue the BIA negotiation with Mainland China. Although majority of Taiwan businesspersons with investment in Mainland China strongly support $\mathrm{Ma}$ in the presidential election, macro and micro challenges still exist for successfully concluding a BIA. Macro challenges include political disputes between Mainland China and Taiwan, disagreements between KMT and DPP, and different focuses of investment between Mainland China and Taiwan. Micro challenges lie in the differences between current Mainland and Taiwan laws.

\section{Three Macro Challenges and Solutions}

There are three macro challenges against concluding a cross-strait BIA. First is the political dispute between Mainland China and Taiwan. Mainland China hopes economic integration can lead to cross-strait political integration. However, Taiwan is against that. The second macro challenge is disagreements between KMT and DPP regarding economic policy towards Mainland China. DPP is much less Mainland-friendly than KMT. Although DPP failed in the presidential election, it still remains influence on Taiwan Legislature [Liwei]. Third, different focuses of investment between Mainland China and Taiwan also impose a serious challenge. Mainland China is interested in investment promotion, hoping more Mainland investment can enter Taiwan market. However, Taiwan hesitates to open its market too fast. Moreover, Taiwan already has heavy investment in Mainland China so it is more attracted by investment protection. If the negotiation of a BIA cannot solve the three macro challenges, it is hard to be successful.

\section{Political Disputes between Mainland China and Taiwan}

Cross-strait political disputes center on sovereignty. Mainland China and Taiwan have different interpretations of "One China". Under the "1992 Consensus [Jiuer Gongshi]", the two sides agree that "One China" may be interpreted differently [Gebiao]. Although Ma Ying-jeou will continue his cooperative economic policy with Mainland China, he adheres to the principle of putting "economics ahead of politics". In Ma's second term, cooperative economic policy will probably not lead to cooperative politic policy. ${ }^{44}$ However, Mainland China aims to use economy to peacefully develop cross-strait relation and ultimately bring Taiwan into one country politically. Noticeably, Mainland's approach towards Taiwan in the past three decades has shifted from "armed liberation" to "peaceful liberation", and to "peaceful unification". 45 On December 31, 2008, Mainland President Hu Jintao used "peaceful development" to replace "peaceful unification."46 This is a significant shift. By emphasizing "peaceful development" instead of "peaceful unification," Hu's policy is more flexible and practicable than his

\footnotetext{
${ }^{44}$ In his second term, Ma will continue the policies of economics ahead of politics, urgent or easy things first. See MA YING-JEOU CONTINUES "No IMMEDiate ReunifiCATION, No InDEPENDENCE, AND No Use OF ForCE" Policy, http://news.163.com/12/0117/08/7NV4Q6CA0001124J.html (last visited Jan 31, 2012), last visited Jan 31, 2012.

${ }^{45}$ See Dennis V. Hickey, Beijing's Evolving Policy toward Taipei: Engagement or Entrapment, 45 IssuES \& STUDIES 31-70 (2009).

${ }^{46} \mathrm{Hu}$ Jintao, Jointly Promoting Cross-strait Relationship and Realize the Great Chinese Renaissance, available at http://news.xinhuanet.com/newscenter/2008-12/31/content_10586495_1.htm, last visited May 20, 2011.
} 
predecessors. Taiwan people have a deep-rooted concern that political integration with Mainland China will harm its democracy. ${ }^{47}$ Lack of mutual trust is a serious obstacle for the future Mainland-Taiwan political relationship. ${ }^{48}$ It will wait to see how Mainland China will develop the "One Country, Two Systems" policy and how "peaceful development" fits with "One Country."

As for the BIA, Mainland China and Taiwan should regard each other as a separate customs territory. In this way, the political disputes regarding sovereignty are not an insurmountable obstacle for economic cooperation. Mainland China and Taiwan entered the WTO as separate customs territory. Therefore, they are equal and can conclude a BIA without creating "One China, One Taiwan [Yizhong, Yitai]." Moreover, if the economies of the two sides are highly integrated, the cost of armed conflicts will be high for both parties; therefore, the cross-strait war threat may decrease. ${ }^{49}$ In this sense, the Mainland investment in Taiwan will also serve Taiwan's political interests.

\section{Disagreements between KMT and DPP}

The disagreement between KMT and DPP regarding economic policy towards Mainland China will negatively influence the BIA. KMT believes bilateral investment cooperation can promote Taiwan economy. DPP argues that the BIA will cause more Taiwan investment to flow to Mainland China, and consequently, Taiwan economy will hollow out. DPP also concerns that Mainland investment will deprive the independence of Taiwan economy. Although DPP is against opening Taiwan market to Mainland investment, it cannot ignore that thousands of Taiwan capital has been invested in Mainland China and the BIA can certainly benefit these Taiwan investors. DPP is also clear that if Taiwan does not open to Mainland investment, Mainland China is not interested in concluding the BIA with Taiwan. Due to these considerations, DPP's opposition to the BIA is limited: it will accept the BIA, but because DPP still holds forty seats in Taiwan Legislature, it will try to push Ma to defer the market entry calendar of Mainland capital.

\section{Investment Promotion VS Investment Protection: Different Interests of Mainland China and Taiwan}

Comparing statistics on Mainland capital invested in Taiwan and those on Taiwan capital invested in Mainland China, ${ }^{50}$ obviously more Taiwan capital has flowed to Mainland China than vice versa. Therefore, Taiwan is more attracted by investment protection, while Mainland China is more interested in investment promotion, namely entering Taiwan market. Due to political disputes between Mainland China and Taiwan, economic policy disagreements between KMT and DPP, and protecting Taiwan local businesses, Ma will hesitate to open Taiwan market

\footnotetext{
${ }^{47}$ For analysis of how Mainland China fundamentally transform its economy without intactness of its political system, see Ronald Gilson \& Curtis Milhaupt, Economically Benevolent Dictators: Lessons for Developing Democracies, 59 Am. J. Comp. L. 227, 227-88 (2011)

${ }^{48}$ Linda Jakobson, A Great Chinese Union--Striving toward a Solution of Taiwan's Unresolved Future Status, 6 Asia Eur. J. 43 , 45 (2008).

${ }^{49}$ Zhaoyang Dai, Jianli Haixia Lianan Jinji Hezuo Zhi Yanjiu [A Study of Establishing Cross-strait Economic Cooperation], 4 ZONGHE JINGZHENLi [COMPREHENSIVE COMPETITION]24, 25 (2010).

${ }^{50}$ See supra notes 19 and 32.
} 
immediately and completely to Mainland investment. In his first term, Ma emphasized that economic cooperation with Mainland China should benefit Taiwan people. Ma will continue this policy in his second term. Therefore, market access requirements will be in hot debate in the BIA negotiation.

Mainland China has provided better market access measures than Taiwan does. However, it still waits to be seen in the BIA whether Mainland China would agree to provide higher protection to Taiwan investment than Taiwan does to Mainland investment. Generally, investment protection treaties require both parties provide the same level protection to each other. Therefore, if Taiwan requests Mainland China to provide better investment protection, it may need to provide the same level of protection to Mainland investors. This will require Taiwan to revise a great number of current laws. ${ }^{51}$ Therefore, it will be a significant challenge to Taiwan.

\section{Micro Challenges and Solutions}

Micro challenges to the BIA come from differences between the current Mainland and Taiwan law. According to the Vice Director Zheng Lizhong of the ARATS, both Mainland China and Taiwan have agreed that a BIA should be concluded under the ECFA framework. Both sides have also reached consensus that the BIA should establish an investment protection mechanism, improve the transparency of investment regulations, gradually reduce restrictive treatments, and promote investment convenience. ${ }^{52}$ Disagreements, according to Zheng, include how to formulate definitions of investment and investor, provisions of investment treatment, investment convenience, nationalization or expropriation as well as compensation.

As for negotiation strategy, considering the differences and similarities of their current investment laws, Mainland China and Taiwan may consider concluding a framework of BIA first. It is hard for both parties to resolve all differences between their investment laws. Issues that both parties have great differences should be left for future negotiations and be solved step by step. New agreements can become amendments added to the BIA. If both parties over emphasize the differences between their current laws, negotiation of the BIA will probably be long, difficult and unfruitful.

Generally a bilateral investment protection agreement should include provisions for definitions of investors and investment, National Treatment, MFN Treatment, investment protection, and dispute resolution. The following analysis compares these provisions in the current Mainland and Taiwan law, WTO law, as well as investment protection agreements concluded by Mainland China and Taiwan with other countries, respectively. It argues that Mainland China and Taiwan can possibly reach agreements on these provisions in the BIA and it hopes to serve as a humble reference for the two governments.

\section{The Scope of Investment}

\footnotetext{
${ }^{51}$ see infra discussions of National Treatment and Most-Favored-Nation Treatment.

52 http://zh.wikipedia.org/wiki/第六次江陳會談, last visited Jan 31, 2012.
} 
The scope of investment is a basic provision in the BIA. The contemporary Mainland and Taiwan law define "investment" differently. Mainland Regulation of Investing in Taiwan does not define "investment". However, Article 3 of Mainland Verification and Approval of Overseas Investment Project Tentative Administrative Procedures (hereinafter "Overseas Investment Approval Procedures") states that: the term "overseas investment projects" shall refer to the activities by which an investment entity obtains overseas ownership, operation and management rights or other relevant rights through the injection of assets and rights such as currency, negotiable securities, physical objects, intellectual property rights or technology, equity or creditors' rights, or through the provision of security. Mainland National Development and Reform Commission approves projects of investing in Taiwan according to Overseas Investment Approval Procedures. ${ }^{53}$ Therefore, the investment that Mainland China permits to invest in Taiwan includes currency, negotiable securities, physical objects, intellectual property rights or technology, equity, stocks, creditors' rights, and other assets, rights, and interests. Article 7 of Taiwan Regulation of Approving People from Mainland Area Investing in Taiwan (hereinafter refer to as "Regulation of Mainland Investment") stipulates that Mainland capital includes cash, machine equipment or raw material, patents, trademarks, copyrights, know-how and other intellectual property rights, as well as other assets approved by Taiwan Economy Department [Jingji Bu]. This provision is the same as Article 6 of Taiwan Regulation of Foreigner Investment and Article 6 of Taiwan Regulation of Overseas Chinese Investment. Therefore, both Mainland and Taiwan definition of "investment" includes cash/currency, machine equipment or raw material, patents, trademarks, copyrights, and other intellectual property rights. It is unclear whether Taiwan Economy Department will recognize equity, creditors' rights, and other assets, rights, and interests as investment. For the following two reasons, the "investment" definition in the BIA should include equity, stocks, debentures of juridical persons and related interests, and creditors' rights.

The first reason comes from the need of reality. Mainland China and Taiwan concluded the Memorandum of Understanding on Cross-Straits Banking Supervision Cooperation (hereinafter "MOU") ${ }^{54}$ on April 26, 2009. The MOU embarks on the cross-strait cooperation in financial supervision, currency management, financial information exchange, and other relevant fields. It offers preferential policies for both parties to enter each other's financial market. Qualified representative offices of Taiwan banks in Mainland China can upgraded to branches. Mainland financial institutions can also enter the Taiwan market and invest in its stocks or bonds markets. For example, on January 19, 2010, Taiwan Stock Exchange states that Mainland capital can purchase listed shares in the fields other than broadcast and TV programs, insurance, telecommunication, transportation, and development of lands. ${ }^{55}$ The MOU will promote crossstrait financial exchange in the long run. Therefore, the two regions may consider including equity, stocks, debentures of juridical persons and related interests into the scope of "investment" in the BIA. Moreover, creditors' rights should also be recognized as investment, because many

\footnotetext{
${ }^{53}$ Art. 2 of Overseas Investment Approval Procedures; art. 3 of Mainland Regulation of Investing in Taiwan.

54 The Memorandum of Understanding on Financial Cooperation between Taiwan and Mainland China embarks on the crossstrait cooperation in finance supervision, currency management, financial information exchange, and other relevant fields. It is concluded on April 26, 2009. It offers preferential policies for both parties to enter each other's market. After its conclusion, seven Taiwan bank offices in Mainland China is eligible to be upgraded as branches; several Mainland banks also plan to open branches in Taiwan. See also MOU on Financial Supervision between Mainland China, Taiwan Takes Effect, http://news.xinhuanet.com/english/2010-01/16/content_12822564.htm, last visited May 4, 2011.

55 The Two Directions for Mainland Capital Investing in Taiwan: Either FDI or Raise Capital, http://www.huaxia.com/tslj/lasq/2010/03/1806280.html, last visited May 4, 2011.
} 
Taiwan companies do business in Mainland China and possibly have claims and liabilities to Mainland companies. Since Mainland companies can invest in Taiwan, it is reasonable to allow them to use their creditor's rights to establish joint ventures with Taiwan business.

Second, many bilateral investment protection agreements concluded between Taiwan and other counties recognize stocks, equity, creditor's rights and other assets, rights, and interests as investment. The Investment Protection Agreement between Taiwan and Malta provides that "investment" includes stocks, equity, debentures or other types of claims to money or to any performance having financial value. ${ }^{56}$ The Investment Protection Agreement between Taiwan and Salvador states that stocks, equity, debentures, or other interests in companies or business organizations, and others transactions and rights with money value, can be considered as investment. ${ }^{57}$ Similar provisions can be found in the Investment Protection Agreement between Taiwan and, Panama ${ }^{58}$, Burkina Faso ${ }^{59}$, Guatemala ${ }^{60}$, respectively. Therefore, advisably Taiwan may consider recognize stocks, equity, debentures and other monetary interests and rights as investment in the BIA, and this is consistent with other investment protection agreements signed by Taiwan.

Moreover, in the BIA, Mainland China and Taiwan may consider re-invested returns as one type of investment. Mainland Regulation of Investing in Taiwan and other related regulations do not indicate whether re-invested returns can be treated as investment. Neither does Taiwan Regulation of Mainland Investment. However, Mainland Law on Protection of Investment by Compatriots from Taiwan provides that investment includes re-invested returns. ${ }^{61}$ Moreover, the Investment Protection Agreement between Taiwan and Panama regards re-invested returns as investment. $^{62}$ The BIA between Mainland China and Taiwan aims to promote mutual investment and improve bilateral protection. A broad definition of investment can help realize this goal. Arguably, Mainland China and Taiwan should consider treating re-invested returns as investment.

\section{The Definition of Investors}

According to Article 4 of Mainland Regulation of Investing in Taiwan, only Mainland enterprise legal persons are eligible investors. ${ }^{63}$ In other words, natural persons and nonenterprise legal persons are ineligible. Mainland definition of investors is too narrow compared with relevant Taiwan law. Article 2 of Taiwan Regulation of Mainland Investment states that Mainland investors include Mainland nature persons, legal persons, associations, and other entities, as well as entities established by Mainland investors in a third region. ${ }^{64}$ Therefore, a sharp contrast exists between Mainland and Taiwan laws regarding "investor". The Investment

\footnotetext{
${ }^{56}$ Art. 1.2-1.3 of the Investment Protection Agreement between Taiwan and Malta.

${ }^{57}$ Art. 2.2-2.3 of the Investment Protection Agreement between Taiwan and Salvador.

${ }^{58}$ Art. 2.2-2.3 of the Investment Protection Agreement between Taiwan and Panama.

${ }^{59}$ Art. 2.2-2.3 of the Investment Protection Agreement between Taiwan and Burkina Faso.

${ }^{60}$ Art. 2.2-2.3 of the Investment Protection Agreement between Taiwan and Guatemala.

${ }^{61}$ Art. 6 of Mainland Law on Protection of Investment by Compatriots from Taiwan.

${ }^{62}$ Art. 2.7 of the Investment Protection Agreement between Taiwan and Panama.

${ }^{63}$ Art. 4 of Mainland Regulation of Investing in Taiwan. This article also provides that Mainland enterprise legal persons should have capital, technology, and management capacities for relevant industries, and the investment should benefit cross-strait relationship and peaceful development, not harmful to national security and unification.

${ }^{64}$ Art. 2 of Taiwan Regulation of Mainland Investment.
} 
Protection Agreement between Mainland China and, Germany, South Korea, respectively, define "investor" as natural persons with PRC nationality, or companies, enterprises or other business entities approved and registered by the PRC government and having rights to do business with foreigners. ${ }^{65}$ Although this definition does not include companies established by Mainland investors in a third region, it covers Mainland natural persons, legal persons, unincorporated business organizations. In the BIA, "investor" can be defined as Mainland or Taiwan natural persons, legal persons, and unincorporated business entities. The current Article 4 of Mainland Regulation of Investing in Taiwan is too restrictive and cannot meet the market demand in practice. Further, this Article is greatly different from Article 2 of Taiwan Regulation of Mainland Investment. Natural persons and unincorporated business entities should be allowed to invest in Taiwan, if they have capital, technology and management capacities related to the investment fields, and if their investment does not harm national unification and security and can benefit cross-strait peaceful development.

Annex V of the ECFA states that "[n]atural person of one Party refers to the natural person that holds the identity certificate of either Party." 66 Because of political disputes, nationality is not an effective standard to determine the citizenship of a natural person. Using identity certificate to determine citizenship is less controversial. ${ }^{67}$ Arguable, the BIA should also adopt this standard. Annex V of the ECFA also provides that "[j]uridical person of one Party refers to the entity that is constituted in either Party according to its regulations, which includes any company, trust, partnership, joint venture, sole proprietorship or association (chamber of commerce)." ${ }^{68}$ Suppose that the BIA adopts the same rule to determine the nationality of a legal person or unincorporated business entities. Namely, if a business entity is considered as a legal person according to Mainland law, Taiwan should recognize it as a Mainland legal person under the BIA. This rule is fine for most of cases. However, problems will occur when involving a business entity established in a third area by Mainland investors. Under Mainland law, such entity is not a Mainland business entity. However, under Taiwan law, it is a Mainland business entity. This is because Mainland China and Taiwan use different criteria to determine the nationality of a business entity. Mainland China uses the place of registration to determine the nationality of a business entity. ${ }^{69}$ However, Taiwan criteria combine shareholders' nationality and actual control. According to Taiwan law, in the following circumstances a business entity established in a third region is regarded as a Mainland business entity: (1) Mainland people ${ }^{70}$ directly or indirectly own more than $30 \%$ of its capital; or (2) Mainland people control this entity. ${ }^{71}$ "Control" refers to any of the following circumstances: (1) Mainland people hold more than 50\% voting shares of the entity; (2) Mainland people can make decisions regarding the entity's finance, operation, and human resources; (3) Mainland people can appoint more than

\footnotetext{
${ }^{65}$ Art. 1.3 of the Investment Protection Agreement between Mainland China and Germany; art. 1.3 of the Investment Protection Agreement between Mainland China and South Korea.

${ }^{66}$ Art. 1 of Annex V Definitions of Service Suppliers Applicable to Sectors and Liberalization Measures under the Early Harvest for Trade in Services.

${ }^{67}$ Chi-Chung Kao, Definition of Investors and Related Issues in Investment Treaty Arbitration Under the Proposed TaiwanChina Bilaeral Investment Agreement, 4 ConTEMP. AsiA ARB. J. 179, 189-193 (2011)

68 Art. 1 of Annex V Definitions of Service Suppliers Applicable to Sectors and Liberalization Measures under the Early

Harvest for Trade in Services.

${ }^{69}$ Art. 184 of the Mainland Opinions to Implement the General Principle of Civil Law.

${ }^{70}$ Mainland people include "natural persons, legal persons, associations, or investment companies established in third region but owned by Mainland companies."

${ }^{71}$ Art. 3 of Regulation of Permitting Mainland People to Invest in Taiwan.
} 
$50 \%$ members of the Board of Directors, and the Board is the power of the organ in the entity; and (4) Mainland people have more than $50 \%$ of the voting right in the Board of Directors. These requirements are very broad. The reason is that Taiwan is conservative towards opening to Mainland investment. Therefore, these requirements aim to cover as more business entities as possible, so as to subject them to restrictive investment regulations.

Recognizing entities established in a third region by an entity of a contracting party as "investors" is not uncommon in investment protection agreements concluded by Mainland China with other countries. For example, Investment Protection Agreements between Mainland China, Switzerland, and France, respectively, also combine the place of registration and the place of actual control to determine nationality of a company. ${ }^{72}$ The Investment Protection Agreement between Mainland China and Switzerland defines "investors" as "natural persons with a nationality of the contracting state; legal entities (including companies, associations, business organizations or other organizations) that are established according to the law of a contracting state and domiciled or operate in the territory of a contracting state; legal entities that are established according to the law of a third state but are effectively controlled by a natural person or a legal entity of a contracting state. ${ }^{73}$ The Investment Protection Agreement between Mainland China and France provides that "investors" refer to natural persons with a nationality of a contracting state, legal persons that are established according to the law of a contracting state and have the headquarter located in the territory of a contracting state, and legal persons that are directly and indirectly controlled by a legal person or natural person of a contracting state. ${ }^{74}$ Clearly, these two definitions cover Mainland natural persons, legal persons, and unincorporated organizations, as well as companies established by Mainland investors in a third region. The Investment Protection Treaty between Mainland China, Switzerland, and France, respectively, do not indicate how to determine "effective control" or "directly or indirectly control". This does not deny the fact that, when concluding investment protection agreements, Mainland China accepts qualified companies established in a third region by an entity of a contracting party as "investors". The cross-strait BIA aims to protect investors and promote cross-strait investment; a broad definition of investors is consistent with this purpose. However, considering the great differences between Mainland and Taiwan law, at the present stage, "investors" in the BIA can be defined as natural persons, legal persons, or unincorporated organizations with a nationality of a contracting region according to its law. When Mainland China and Taiwan agree upon how to determine the nationality of a business entity established in a third region by a natural person, legal person, or unincorporated business entities of a contracting party, they should add this criterion to the BIA.

\section{National Treatment}

Generally, National Treatment means a party shall accord to investors of the other party and their investments treatment no less favorable than it accords to its own like investments and investors with respect to admission, establishment, acquisition, expansion, management, conduct,

\footnotetext{
${ }^{72}$ Art. 1.2 of Mainland China and France Mutually Promoting and Protecting Investment Treaty; and art. 1.2 of Mainland China and Switzerland Mutually Promoting and Protecting Investment Treaty.

${ }^{73}$ Art. 1.2 of the Investment Protection Agreement between Mainland China and Switzerland.

${ }^{74}$ Art. 1.2 of the Investment Protection Agreement between Mainland China and France.
} 
operation, maintenance, use, liquidation, sale, and other forms of disposal of investments. ${ }^{75}$ In order to attract foreign investment, host regions generally offer National Treatment to foreign investors. For example, both Taiwan Regulation of Foreign Investment and Regulation of Overseas Chinese Investment indicate that the rights and obligations of businesses established by foreign investment shall be the same as Taiwan local businesses, except as otherwise provided by the law. ${ }^{76}$ However, Taiwan Regulation of Mainland Investment and relevant laws do not offer National Treatment to Mainland investment. This deficiency is harmful to attract Mainland investment.

Regarding Mainland law, although neither Law on Protection of Investment by Compatriots from Taiwan nor its Implementation Regulation explicitly uses the term of National Treatment, in practice Mainland China offers National Treatment to Taiwan investment. For example, Article 13 of Mainland Law on Protection of Investment by Compatriots from Taiwan states that Taiwan investment enterprises shall enjoy the preferential treatment according to the relevant provisions made by the State Council concerning encouraging investment by compatriots from Taiwan. Before the Mainland new Enterprise Income Tax Law was implemented in 2008, Taiwan investment enterprises enjoyed the same preferential tax exemption and reduction as other foreign enterprises. In terms of tax, the treatment that Taiwan investment enterprises have is better than Mainland enterprises. According to Article 19 of the Implementation Regulation of the Mainland Law on Protection of Investment by Compatriots from Taiwan, Taiwan investment enterprises enjoy the same treatment as Mainland enterprises when purchasing machine equipment, raw material, water, electricity, heat, transportation, labor service, advertisement, telecommunication and other service. Taiwan investors and Taiwanese working in Mainland China shall enjoy the same treatment as Mainland people in terms of transportation, telecommunication, touring, hotel accommodation, real estate purchasing and other aspects. This provision represents National Treatment. Therefore, according to the principle of reciprocity, Taiwan should offer National Treatment to Mainland investment.

All investment protection agreements concluded between Taiwan and foreign countries offers National Treatments. For example, the Investment Protection Agreement between Taiwan and Panama provides that the contracting parties promise to offer fair, equal and nondiscriminatory treatment to the investment from the other party according to domestic law and international law...contracting parties offer the same treatment to investors from the other party as its own nationals. ${ }^{77}$ Moreover, National Treatment to foreign investors can be found in Article 3 of the Investment Protection Agreement between Taiwan and Macedonia, Article 5 of the Investment Protection Agreement between Taiwan and Salvador, Article 3 of the Investment Protection Agreement between Taiwan and Burkina Faso, Article 3 of the Investment Protection Agreement between Taiwan and Guatemala. Taiwan accepts National Treatment in its investment protection agreements with foreign countries; therefore, the National Treatment provision should be included in the cross-strait BIA.

\section{MFN Treatment}

\footnotetext{
${ }^{75}$ See Art. 4 of Mainland-ASEAN Investment Agreement, art. 3 of General Agreement on Tariffs and Trade 1994, and art. 17 of General Agreements on Trade in Services.

${ }^{76}$ Art. 17 of Taiwan Regulation of Foreign Investment and Regulation of Overseas Chinese Investment.

${ }^{77}$ Art. 3 of Investment Protection Agreement between Taiwan and Panama.
} 
In international investment protection agreements, the MFN Treatment provision generally is formulated as follows: each party shall accord to investors of the other party and their investments treatment no less favorable than that it accords to like investment or investors of any other country with respect to admission, establishment, acquisition, expansion, management, conduct, operation, maintenance, use, liquidation, sale, and other forms of disposal of investments. ${ }^{78}$ The first issue related to whether the cross-strait BIA should contain a MFN Treatment provision is whether this provision is suitable to the Mainland-Taiwan relation from the perspective of international law. Although the two regions interpret "one China" differently in the Ninety-two Consensus, the MFN Treatment provision does not involve the sovereignty issue so will not shadow Mainland-Taiwan relation in terms of international law. Mainland China and Taiwan, as separate customs territories, are WTO members. MFN Treatment is a fundamental principle in the WTO and applicable between Mainland China and Taiwan. The word "nation" in the MFN Treatment provision looks apparently sensitive. However, considering the WTO rules, the word "nation" should be understood as separate customs territories.

Although Mainland Law on Protection of Investment by Compatriots from Taiwan and its Implementation Regulation do not provide a provision of MFN Treatment, other Mainland laws concerning foreign investment actually offer this treatment to Taiwan investment. For example, Article 82 of Mainland Implementation Regulation of Foreign Enterprise Law and Article 57 of Mainland Implementation Regulation of Cooperative Joint Venture Law both provide that establishment of a contractual joint venture or a wholly owned enterprise by companies, enterprises and other economic organizations or individuals from Taiwan shall be handled with reference to this regulation. Here "with reference to [Canzhao Shiyong]" means enterprises established by Taiwan investment should enjoy the same treatment as enterprises established by other foreign investment. Mainland Foreign Investment Guidance Category also does not distinguish Taiwan investment from other foreign investment, and therefore Taiwan investment actually enjoys the MFN Treatment in Mainland China. Since in practice, Mainland China has already offered MFN Treatment to Taiwan investment, Mainland China should consider adding this treatment to the BIA.

In the Investment Protection Agreement between Taiwan and, Macedonia, Salvador, Burkina Faso, and Guatemala, respectively, Taiwan promises to offer MFN Treatment to investment from these countries. ${ }^{79}$ However, as for market entry, unlike Mainland law, Taiwan law distinguishes Mainland investors from other foreign investors, without offering MFN Treatment. ${ }^{80}$ Taiwan imposes more restrictions on Mainland investment than other foreign investments. ${ }^{81}$ For example, Taiwan Regulation of Foreign Investment provides that if foreign investment negatively influences national security, public order, good moral or affects citizen's

\footnotetext{
${ }_{78}^{78}$ See art. 5 of Mainland-ASEAN Investment Agreement; art. 2 of General Agreement on Trade in Services.

${ }^{79}$ Art. 3 of the Investment Protection Agreement between Taiwan and Macedonia, art. 5 of the Investment Protection Agreement between Taiwan and Salvador, art. 3 of the Investment Protection Agreement between Taiwan and Burkina Faso, and art. 3 of the Investment Protection Agreement between Taiwan and Guatemala.

${ }^{80}$ Art. 3 of Regulation of Permitting Mainland People to Invest in Taiwan.

${ }^{81}$ Hong Yin, Taiwan Diqu “Luzhi Rutai” Xiangguan Falv Fenxi [Analysis of Taiwanese Law of "Mainland Capital Investing in Taiwan”], 11 Hunan Sheke Xuebao [Journal of Human InStitute OF Socialism] 70, 71 (2010).
} 
health, and has other situations forbidden by law, the investment application should be denied. ${ }^{82}$ Mainland investors are subject to laws applicable to foreign investors in general (e.g., Regulation of Foreign Investment) and laws for Mainland capital in particular (e.g., Regulation of Mainland Investment). According to the Regulation of Mainland Investment, circumstances where Mainland investment application should be denied include: (1) monopoly; (2) politically, socially, or culturally sensitive; (3) influencing national security; and (4) affecting economic or financial stability. ${ }^{83}$ The Regulation of Permitting Mainland People to Obtain or Transfer Real Estate in Taiwan states that Mainland people shall be denied to own or transfer real estates in Taiwan if the real estates influence the important constructions in Taiwan, involve land monopoly and speculation, affect the whole national land development, or impact national security and social stability. ${ }^{84}$ Therefore, compared with other foreign investments, Mainland investments are subject to more restrictive requirements.

Moreover, Taiwan uses the negative-listing principle for foreign investment, namely any unlisted industries are open to foreign investors. However, Taiwan implements the positivelisting principle for Mainland investment, 85 meaning that only listed projects are open for Mainland investment. 86 Therefore, fewer industries are open to Mainland investment than other foreign investment. Additionally, Taiwan allows Mainland investors to stay in Taiwan for a much shorter period than other foreign investors. Regulation of Permitting Mainland People to Obtain or Transfer Real Estate in Taiwan allows Mainland people to stay in Taiwan only for ten days since the entry for purchasing or transferring real estates. ${ }^{87}$ If necessary, the stay can be extended once, and for maximum another ten days. ${ }^{88}$ The total stay in Taiwan in one year shall be less than one month. ${ }^{89}$ Regulation of Mainland People Coming to Taiwan to Attend Business Activities provides that Mainland people, who come to Taiwan for business visits, commercial investigation, conferences, speeches, and trade fair, shall stay less than 14 days in Taiwan. ${ }^{90}$ Mainland people can stay less than 3 months in Taiwan, if his or her purpose is to study business, examine goods, conduct after sales service, and provide technology instruction and other contracting activities. ${ }^{91}$ These requirements are not applicable to other foreign investors. ${ }^{92}$ Many Mainland investors believe these requirements are too restrictive because one month is too short to conduct a real estate deal and 14 days are not sufficient to finish a complicated business negotiation.

Giving MFN Treatment to Mainland investment in the BIA will be a serious challenge to Taiwan because this requires amending many Taiwan laws. Although incumbent Ma Ying-jeou was re-elected as Taiwan President, his vote (51.6\%) is less than that he earned in $2008(58.45 \%)$.

\footnotetext{
${ }^{82}$ Art. 7 of Regulation for Foreign Investment. A similar article is Art. 6 of Mainland Profit-making Entities Establish Branches or Representative Offices in Taiwan.

${ }^{83}$ Art. 8 of Regulation to Permit Mainland People to Invest in Taiwan.

${ }^{84}$ Art. 3 of The Regulation of Permitting Mainland People to Obtain or Transfer Real Estate in Taiwan.

${ }^{85}$ Taiwan authority adopted "Conservative First, Loose Later", " proceed in an orderly way and step by step" "Broaden the Scope when Successful". The first stage of opening projects was effective since June 30, 2009. The second stage of opening projects were released on March 2, 2011. The Second stage expended the projects opened on the first stage.

${ }^{86}$ Taiwan lists 192 projects that are open to Mainland investors.

${ }^{87}$ Art. 18 of The Regulation of Permitting Mainland People to Obtain or Transfer Real Estate in Taiwan.

${ }^{88} I d$.

${ }^{89}$ Id.

${ }^{90}$ Art. 16 of Regulation of Mainland People Coming to Taiwan to Attend Business Activities.

${ }^{91}$ Id.

${ }^{92} I d$.
} 
The vote to DDP increased from $41.55 \%$ in 2008 to $45.63 \%$ in 2012 . Therefore, the political situation in Taiwan is still very complicated. Probably, Taiwan will hesitate to offer MFN Treatment to Mainland investment in all fields. The two regions should try to include a partial MFN Treatment provision in the BIA, namely in all areas that Taiwan allows Mainland investment to access, Taiwan agrees to offer MFN Treatment.

\section{Security Exception}

Due to political differences, ${ }^{93}$ probably Taiwan will request the BIA should include a security exception provision as exception to the National Treatment and MFN Treatment. For Taiwan, security exception is especially important to protect its interests and to win the opposing DPP's support to the BIA. However, for Mainland China, a broad security exception will make the BIA in name but not in deed. Currently, the Taiwan law concerning security exception for Mainland investment includes Article 6 of Regulation of Mainland Investment, which provides that all investors with Mainland military background shall not be allowed to invest in Taiwan. ${ }^{94}$ Article 17 of Taiwan Land Law states that lands of forts, armaments, and borders shall not be transferred, mortgaged, or lent to foreigners. ${ }^{95}$ The Regulation of Permitting Mainland People to Obtain or Transfer Real Estate in Taiwan further indicates that Mainland people are forbidden to own lands in harbors and other areas that may affect Taiwan's national security. ${ }^{96}$ Additionally, Mainland investors shall not acquire, establish or transfer ownership upon real estates that negatively affect Taiwan national security or social stability. ${ }^{97}$ However, contemporary Taiwan law does not clearly indicate how to determine Mainland investment may harm Taiwan security. Lack of explicit criteria blurs security exception. If Taiwan insists on adding a security exception provision in the BIA, the two regions should work together to formulate explicit, clear, feasible criteria to determine what investment may harm the security of hosting region. Either party should not unilaterally expand the scope of security exception. Otherwise, the National Treatment and MFN Treatment provisions in the BIA will be in vain.

\section{Investment Protection}

An investment protection provision is the central part of the BIA. Generally, it is constituted by three parts: no expropriation/nationalization, exception, and compensation. No expropriation/nationalization generally is formulated as: a party shall not expropriate, nationalize or take other similar measures against investment of investors of the other party. "Other similar measures" means indirect expropriation/nationalization. It refers to measures that are not in the name of expropriation or nationalization but have similar effects as them. Many investment protection agreements signed by Mainland China and by Taiwan with other countries explicitly cover indirect expropriation/nationalization. For example, the Investment Protection Agreement between Mainland China and France stipulates that, in its territory or sea, a party shall not expropriate or nationalize investment from the other party, and shall refrain from using any other measures with direct or indirect similar expropriation or nationalization effects unless these

\footnotetext{
${ }^{93}$ See Supra note 4.

${ }_{95}^{94}$ Art. 6 of Taiwan Regulation of Mainland Investment.

${ }^{95}$ Article 17 of Taiwan Land Law. If a foreigner inherit such land, he/she should sell this land to a Taiwan person within three years of inheritance.

${ }_{96}^{96}$ Art. 2 of The Regulation of Permitting Mainland People to Obtain or Transfer Real Estate in Taiwan.

${ }^{97}$ Id, art. 3 .
} 
measures are for public interests ${ }^{98}$ and applied non-discriminatorily. ${ }^{99}$ The Investment Protection Agreement between Mainland China and South Korea ${ }^{100}$ and that between Mainland China and Switzerland $^{101}$ also contain similar indirect expropriation/nationalization provisions. Article 5 of the Investment Protection Agreement between Taiwan and Macedonia also indicates that investment from either party shall not be nationalized, expropriated or suffer from measures with similar effects of nationalization or expropriation in the territory of the other party. The Investment Protection Agreement between Taiwan and, Salvador ${ }^{102}$, Panama ${ }^{103}$, Burkina Faso ${ }^{104}$, Guatemala $^{105}$, respectively also contain similar provisions.

Unlike international agreements, Mainland and Taiwan domestic laws do not promise no indirect nationalization/expropriation. Mainland Law on Protection of Investment by Compatriots from Taiwan and its Implementation Regulation promise not to nationalize and expropriate Taiwan investment. ${ }^{106}$ Whether this covers indirect nationalization/expropriation is unclear. Taiwan Regulation of Foreign Investment and Regulation of Overseas Chinese Investment both indicate that no nationalization or expropriation shall be made to a company that is in the first twenty years of its operation and more than $45 \%$ of its investment belongs to foreigners or overseas Chinese. ${ }^{107}$ However, Taiwan Regulation of Mainland Investment does not indicate nationalization/expropriation will not be imposed upon Mainland investment. Therefore, in order to protect cross-strait investment and strengthen investors' confidence, the BIA should contain a no-nationalization/expropriation provision.

Considering Mainland and Taiwan domestic laws as well as investment protection agreements concluded by them, arguably, the BIA should explicitly provide neither direct nor indirect nationalization/expropriation will be imposed on investment from contracting parties. This conforms to the purposes of investment protection and promotion. Nevertheless, at present Mainland China and Taiwan cannot easily agree upon the definition of indirect nationalization/expropriation. One reason is that this concept is hard to define by an exhaustive list. For example, one scholar suggests indirect nationalization/expropriation mainly include (1) the host region hinders or actually expropriates a foreign property owner from using its property; (2) due to the host region's controls, a foreign enterprise loses its autonomy in deciding salary and employment of its labor, price of its products, import and export, or the host region imposes excessive taxes on or support unfair competition against the foreign enterprise, and etc.; (3) the host region puts a foreign company under its temporary control and keep this control in an

\footnotetext{
${ }^{98}$ For meaning of public interests, see art. 8 of Regulations for the Expropriation of and Compensation for Housing on Stateowned Land, published and effective on January 21, 2011.

${ }^{99}$ Art. 5.2 of Mainland-France Treaty for Mutually Promoting and Protecting Investment (hereinafter "Mainland-France Investment Protection Treaty"). A similar article is art. 6.1 of Mainland-Switzerland Treaty for Mutually Promoting and Protecting Investment (hereinafter "Mainland-Switzerland Investment Protection Treaty").

${ }^{100}$ Art. 5 of the Investment Protection Agreement between Mainland China and South Korea.

${ }^{101}$ Art. 6.1 of the Investment Protection Agreement between Mainland China and Switzerland.

${ }^{102}$ Art. 8 of the Investment Protection Agreement between Taiwan and Salvador.

${ }^{103}$ Art. 8 of the Investment Protection Agreement between Taiwan and Panama.

${ }^{104}$ Art. 8 of the Investment Protection Agreement between Taiwan and Burkina Faso.

${ }^{105}$ Art. 8 of the Investment Protection Agreement between Taiwan and Guatemala.

${ }^{106}$ Art. 4 of Mainland Law on Protection of Investment by Compatriots from Taiwan and art. 24 of its Implementation Regulation.

${ }^{107}$ Art. 13 of Taiwan Regulation of Foreign Investment and art. 14 of Taiwan Regulation of Overseas Chinese Investment.
} 
undefined term, and etc. ${ }^{108}$ However, this list is not exhaustive. Overall, indirect nationalization/expropriation refers to measures have similar effects as nationalization or expropriation in practice, although they may not be in the name of nationalization/expropriation. The definition of indirect nationalization/expropriation will be left to the future judicial practice in both Mainland China and Taiwan.

In the investment protection provision, exceptions generally refer to that a host region can directly or indirectly nationalize or expropriate investment from the other party for a public purpose, according to applicable domestic laws (including legal procedures) of the hosting region and in a non-discriminatory manner. ${ }^{109}$ Such public interests exception provision exists in Mainland and Taiwan domestic laws and in the investment protection agreements that they concluded with foreign countries. For example, the investment protection agreements concluded between Mainland China and, France ${ }^{110}$, Switzerland ${ }^{111}$, South Korea ${ }^{112}$, ASEAN ${ }^{113}$, respectively, all contains the public purpose exception provision. A similar provision can be found in investment protection agreements between Taiwan and, Macedonia ${ }^{114}$, Salvador ${ }^{115}$, Panama ${ }^{116}$, Burkina Faso $^{117}$, and Guatemala ${ }^{118}$. Mainland Law on Protection of Investment by Compatriots from Taiwan and its Implementation Regulation also provide that under special circumstances, when public interests require, investment by investors from Taiwan may be nationalized or expropriated according to legal procedures. ${ }^{119}$ According to Taiwan law, governments can also nationalize/expropriate private property for public interests purposes. For example, Mainland investors can acquire lands according to the Regulation of Permitting Mainland People to Obtain or Transfer Real Estate in Taiwan. Taiwan Regulation of Land Expropriation handles land expropriation. ${ }^{120}$ Its Article 3 authorizes government to expropriate private lands for public affairs such as: national defense, public transportation, public utility, water conservancy, public sanitary and environmental protection, public architecture, education, academic and cultural affairs, social welfare, and other affairs for public interests. ${ }^{121}$ As a conclusion, the cross-strait BIA may adopt public interests exception since it exists in both Mainland and Taiwan law. However, Mainland China and Taiwan should not interpret public interests too broad and harm investors' interests.

\footnotetext{
${ }^{108}$ Zhongyi Lee, Dui Taishan Touzhi Zhengshou Jiqi Buchang de Jidian Shikao [Analysis of Expropriation and Compensation to Taiwan Businesspersons], Fujian Faxue [Fujian Law Journal] 12, issue 4 (2010).

${ }^{109}$ See art.8 of Mainland-ASEAN Investment Protection Agreement; art. 4 of Mainland Law on Protection of Investment by Compatriots from Taiwan.

${ }^{110}$ Art. 5 of the Investment Protection Agreement between Mainland China and France.

${ }^{111}$ Art. 6.1 of the Investment Protection Agreement between Mainland China and Switzerland.

${ }^{112}$ Art. 5 of the Investment Protection Agreement between Mainland China and South Korea.

${ }^{113}$ Art. 8 of Mainland-ASEAN Investment Protection Agreement.

${ }^{114}$ Art. 5 of the Investment Protection Agreement between Taiwan and Macedonia.

${ }^{115}$ Art. 8 of the Investment Protection Agreement between Taiwan and Salvador.

${ }^{116}$ Art. 5 of the Investment Protection Agreement between Taiwan and Panama.

${ }^{117}$ Art. 6 of the Investment Protection Agreement between Taiwan and Burkina Faso.

${ }^{118}$ Art. 4 of the Investment Protection Agreement between Taiwan and Guatemala.

${ }^{119}$ Art. 4 of Mainland Law on Protection of Investment by Compatriots from Taiwan and art. 24 of its Implementation Regulation.

${ }^{120}$ Taiwan Regulation of Land Expropriation was amended on Dec. 11, 2002 and its Implementation Regulation was published on Apr. 17, 2002.

${ }^{121}$ Art. 5 of Taiwan Regulation of Land Expropriation.
} 
As for loss compensation, investment protection agreements generally provide that the nationalizing/expropriating party should make promote compensation to the investors of the other party, and the compensation can be freely transferred overseas. However, how to calculate compensation is a controversial issue. The Mainland Implementation Regulation of the Law on Protection of Investment by Compatriots from Taiwan states that compensation to nationalized/ expropriated Taiwan investment shall be equal to the value on the date of expropriation, including interests calculated from the date of expropriation to the date of payment. ${ }^{122}$ Taiwan investors can exchange foreign currencies, transfer money back to Taiwan or overseas. ${ }^{123}$ However, this law does not specify how to calculate "the value on the date of expropriation," and this may create controversies in practice.

Taiwan law on compensation is also insufficient. Taiwan Regulation of Land Expropriation indicates that the owner of the expropriated land shall be compensated by the entity that uses the land subsequently. ${ }^{124}$ This entity shall transfer all the compensation to a competent government agency that will pay to the prior owner of the expropriated land. ${ }^{125}$ However, the Regulation of Land Expropriation does not indicate how to calculate the compensation. Moreover, if Mainland businesspersons invest in Taiwan, they have properties other than lands. Therefore, Regulation of Land Expropriation cannot solve all the nationalization/expropriation risks confronted by Mainland investors. Taiwan Regulation of Compensating Requisition and Expropriation in Disaster Relief states that Taiwan government shall compensate the owners of properties requisitioned or expropriated for disaster relief. ${ }^{126}$ The government shall pay compensation at the end of every thirty days of requisition or expropriation. ${ }^{127}$ If the government requisitions vehicles for disaster relief, compensation shall be made according to relevant regulations issued by Taiwan Ministry of Transportation. ${ }^{128}$ Therefore, if Mainland investors' properties are expropriated for disaster relief, they can be compensated according to Taiwan Regulation of Compensating Requisition and Expropriation in Disaster Relief. However, this Regulation does not indicate how to calculate compensation either. Moreover, it applies only to natural disaster such as earthquake and hurricane, and disaster caused by serious fire, explosion, air crash, marine perils, electric transmission line, and petroleum pipe leakage. ${ }^{129}$ These disasters do not cover all the risks that investors are confronted. Investors are often more concerned with risks such as nationalization, war, or indirect nationalization/requisition for public interests. Therefore, the scope of Taiwan Regulation of Compensating Requisition and Expropriation in Disaster Relief is too narrow, and it cannot solve compensation issues of nationalized/expropriated Mainland investment.

Different from deficient domestic laws, many international investment protection agreements concluded by Mainland China and by Taiwan with other countries provide detailed

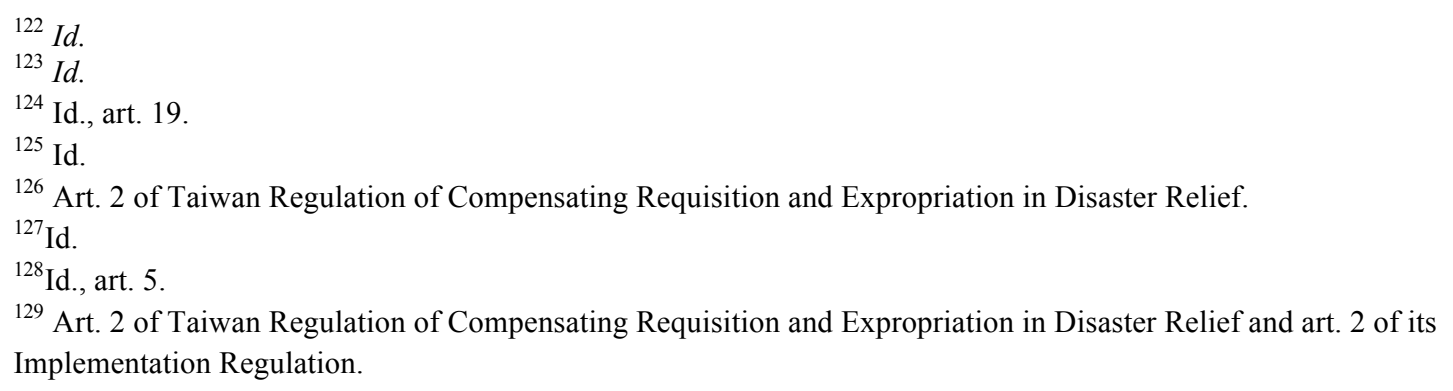


rules for compensation. Useful insights can be drawn from these agreements. International Investment Protection Agreements between Mainland China and, ASEAN, Switzerland, as well as South Korea, respectively, have similar provisions for compensation: compensation shall be equal to the market value of the expropriated investment on the date of expropriation or right before the general public or the investor is informed of expropriation, whichever is earlier; if market value is hard to determine, on the base of fairness and equality, compensation should be determined by considering the factors such as original value of investment, depreciation, and the amount of capital that has been transferred out of Mainland China; the anticipated profits shall be excluded; the compensation shall not be delayed and shall include interests calculated by the prevailing market rate from the date of expropriation to the date of payment. ${ }^{130}$ The Investment Protection Agreement between Taiwan and Macedonia indicates that the amount of compensation shall be the market value of the expropriated investment on the date of expropriation or right before expropriation is publically announced, whichever is earlier, and the compensation shall not be delayed and shall include interests calculated by the London Interbank Offered Rate from the date of expropriation to the date of payment. ${ }^{131}$ The Investment Protection Agreement between Taiwan and Salvador, Panama, respectively both provide that the amount of compensation shall be the market value of the expropriated investment one day before the general public is informed of expropriation; if the value is hard to determine, compensation shall be made on the publicly recognized fair value. ${ }^{132}$ Therefore, the commonness between the investment protection agreements signed by Mainland China and by Taiwan with foreign countries is to determine compensation by the market value of the expropriated investment before the general public or the investor is informed of expropriation. The wording "one day before" is clearer and more practical than "right before". Therefore, the compensation provision in the BIA may includes, among others, that compensation shall be equal to the market value of the expropriated investment on the date of expropriation or one day before expropriation is publicly announced, whichever is earlier; if market value is hard to determine, on the base of fairness and equality, the compensation shall not be delayed and shall include interests calculated by the prevailing market rate from the date of expropriation to the date of payment, and the compensation can be freely transferred overseas. This wording is clearer and more feasible, so may cause less disputes in practice.

\section{Dispute Resolution}

Dispute resolution between an investor and a host region is a sensitive issue in the crossstrait context. Mainland China always avoids internationalizing any cross-strait investment disputes. Currently the prevailing way for settling disputes between a Taiwan investor and Mainland government is to combine local remedy and consultation between SEF and ARATS. For example, if a Taiwan investor is unsatisfied with the compensation of expropriation from Mainland government. He may litigate the case in a Mainland court. If the result of litigation is still unsatisfactory, he may submit his different opinions to the Mainland National Taiwan Affairs Office, SEF or ARATS. ${ }^{133}$ The dispute may be finally resolved by consultation between

\footnotetext{
${ }^{130}$ Art. 6.1 of the Investment Protection Agreement between Mainland China and Switzerland; art. 5.3 of the Investment Protection Agreement between Mainland China and South Korea.

${ }^{131}$ Art. 5 of the Investment Protection Agreement between Taiwan and Macedonia.

${ }^{132}$ Art. 8.2 of the Investment Protection Agreement between Taiwan and Salvador; art. 6 of the Investment Protection Agreement between Taiwan and Panama.

133 See http://www.seftb.org/mhypage.exe?HYPAGE=/02/02_3.asp. (last visited March 29, 2012)
} 
SEF and ARATS. Because of sovereignty disputes, local remedies plus consultation between SEF and ARATS is currently a major way to coordinate the interests of Mainland China and Taiwan and solve investment disputes.

For a long time, SEF-ARATS consultation is the major channel to handle cross-strait issues. ${ }^{134}$ Before the conclusion of the ECFA, SEF-ARATS consultation has been widely adopted by many cross-strait agreements. For example, the Cross-Strait Medicine and Sanitation Cooperative Agreement states that in case of disputes, the two regions should organize consultation as soon as possible; the consultation should be arranged within 15 working days after one region's request. ${ }^{135}$ The SEF-ARATS consultation is also the dispute resolution mechanism under the Safeguard Measures between the Two Regions Applicable to Products under the Early Harvest for Trade in Goods, ${ }^{136}$ the MOU, ${ }^{137}$ and the Cross-Strait IP Protection Cooperation Agreement. 138

Generally, ARATS-SEF consultation is conducted in three steps: First, the officials in SEF and ARATS communicate and prepare for higher-level meetings. Second, after several communications between officials, vice director's meeting will be held. Vice directors meetings prepare and decide the schedule of director's meeting. Third is the bi-annual director meeting. With broadening of issues and diversifying of topics, the ARATS-SEF director's consultation may not effectively and efficiently resolve problems in the future cross-strait economic development. ${ }^{139}$ Therefore, on June 14, 2008, Ma Yingjeou proposed to establish a multi-level consultation system. He stated, "the so-called cross-strait coordination mechanism can be multilevel, and depending on the importance of the topics, consultation can be carried out in either Mainland China or Taiwan"140 and "in the future, the SEF and ARATS can use the most effective ways to carry out many groups of negotiations."141

Institution-building can "lock-in" inter-regional agreements and ensure a credible commitment from the parties. ${ }^{142}$ This is especially relevant in the cross-strait context considering the KMT and DPP fiercely contested on their Mainland policies. ${ }^{143}$ Moreover, institution building may also help establish multi-level cross-strait consultation. On January 6, 2011,

\footnotetext{
${ }^{134}$ Cai, supra note 17 , at 32 .

${ }^{135}$ Art. 28 of Cross-Strait Medicine and Sanitation Cooperative Agreement, concluded on December 21, 2010.

${ }^{136}$ This document is the Annex III of the ECFA. Its para. 1 states that "If, as a result of the implementation of the Early Harvest Program by an importing Party, any specific product thereof is being imported from the other Party in such increased quantities, absolute or relative to the production of the importing Party, and under such conditions as to cause or threaten to cause serious injury to the industry of the importing Party that produces like or directly competitive products, the importing Party may request consultations with the other Party to seek a mutually satisfactory solution." If parties fail in consultation and a party determines to take a safeguard measure, the party may increase the tariff rate applicable to the product concerned up to the level of non-interim tariff rate generally applied to the members of the WTO at the time when such a safeguard measure between the two parties is taken. The question, whether the two parties would go to WTO for a decision, is answered negatively. For one thing, WTO is not comprehensive to cover all issues included by the ECFA. For the other, Mainland China is not willing to submit its dispute with Taiwan to the WTO, because Mainland China believes that disputes with Taiwan are its domestic affairs.

${ }^{137}$ Art. 10 of the MOU.

${ }^{138}$ Art. 15 of Cross-Strait IP Protection Cooperation Agreement, signed on June 29, 2010.

${ }^{139}$ Cai, supra note 17 , at 32

${ }^{140} I d$. at 32

${ }^{141} I d$. at 32

${ }^{142}$ Stefan P. Fleischauer, Non-State Negotiations between China and Taiwan-- On the Road to European-Style Integration?, 26 1, 17 (2008)

${ }^{143} \mathrm{Id}$. at 17
} 
Mainland China and Taiwan jointly established a Cross-Straits Economic Cooperation Committee according to the ECFA. The Committee will conduct consultations necessary for implementing the ECFA, monitoring and evaluating its implementation, interpreting the provisions of the ECFA, and notifying the two parties each other's important economic and trade information. ${ }^{144}$ Moreover, before the establishment of the dispute settlement procedures, the Committee will settle any dispute over the interpretation, implementation, and application of the ECFA. ${ }^{145}$ The Committee may also set up working group(s) and convene meetings for issues pertaining to the ECFA. ${ }^{146}$ Its conveners are Vice Director of ARATS and Associate Director of SEF. Mainland representatives are constituted by vice minister of the Department of Commerce, and experts from the National Taiwan Affairs Office, the Ministry of Finance, the National Development and Reform Commission, the General Administration of Customs and other seven government agencies. Considering the member of the Committee, it will become the first direct governmental interregional institution to handle cross-strait issues under the ECFA. The Committee provides a venue of regular direct consultation between Mainland and Taiwan officials. Compare with the SEF-ARATS consultation, the Committee will be more efficient and effective in implementing and developing ECFA. However, considering historically when the DPP took power in Taiwan, SEF's activities were frozen. Therefore, it waits to be seen whether the Committee will be like the SEF and be subject to the partisan in Taiwan.

At present stage, in the BIA, Mainland China and Taiwan may consider adopt the combination of local remedy and SEF-ARATS consultation, or Cross-Straits Economic Cooperation Committee consultation for dispute resolution. Namely, if an investor is unsatisfied with a final judgment of a host region, it should be allowed to entrust SEF, ARATS, or the representatives of its home region to discuss the case with the government of the host region. In the future, when more consensuses are built, Mainland China and Taiwan may consider using third-party arbitration for solving disputes between an investor and a host region. Hong Kong may be a natural venue for arbitration.

\section{Conclusion}

The above discussion demonstrates that some contemporary Taiwan laws may be against National Treatment and MFN Treatment. Taiwan will be reluctant to revise these laws. On the one hand, Taiwan hopes a broad national security exception clause while requiring Mainland China to provide a comprehensive investment protection to Taiwan investment. On the other hand, Mainland China will be against a broad national security exception clause and require Taiwan to provide equal and fair treatment to Mainland investment. Therefore, in the current status, the two regions cannot negotiate a full-fledged BIA. The BIA will be a framework only. SEF and ARATS or the Cross-Straits Economic Cooperation Committee will play a significant role in interpreting and developing this Agreement. New consensus can be added to the Agreement as an amendment.

\section{BIA and Cross-strait Political Prospects}

\footnotetext{
144 Art. 10.1 of the ECFA.

${ }^{145} I d$.

${ }^{146} I d$, at arts. 10.2 and 10.3 .
} 
A BIA will help Mainland capital moves to Taiwan and balance the current Taiwan-toMainland-only investment flow. Economy in Mainland China and Taiwan will be further integrated. The question, whether economic integration can lead to cross-strait political integration, has raised a hot debate in the two regions and brought attention around the world. Many scholars are fascinated about whether economic cooperation will spillover to the political field, and whether Mainland-Taiwan would follow the EU example evolving from economic cooperation to political integration. Neofunctionalism, intergovernmentalism, and liberal intergovernmentalism, ${ }^{147}$ the three leading integration theories, all answer the question negatively.

First, the spillover effect of Neofunctionalism will less likely move cross-strait economic integration to political integration between Mainland China and Taiwan. According to Neofunctionalism, economic integration will generate spillover, and consequently integration can move from low to high political areas. ${ }^{148}$ Professor Stefan P. Fleischauer states that ${ }^{149}$

"Negotiations between the two sides of the Taiwan Strait have not moved much beyond (and in many fields remain far behind) issues which are considered the very essentials of normal interstate exchange and simply do not carry enough potential for further integration."

This argument is correct. The current cross-strait economic exchange, such as direct sea, airline, and postal services, the MOU, the ECFA, and the future BIA, are far less comprehensive and liberal compared to the ASEAN Plus One Agreement. It has not gone beyond the normal interregional exchange. ${ }^{150}$ Moreover, Mr. Ma Yingjeou has emphasized that the only aims of ECFA is to boost economy and has no political implications. ${ }^{151}$ For example, Mainland China originally proposed CEPA ${ }^{152}$ as the name for cross-strait economic agreement. Taiwan rejected it, because Taiwan believes the legal status of Taiwan is different from that of Hong Kong and Macao $^{153}$ and using the name of CEPA will politically dwarfed Taiwan.

Second, according to Intergovernmentalism and Liberal Intergovernmentalism, the crossstrait economic integration will not lead to political integration either. ${ }^{154}$ The reason is that Taiwan may consider economic power as "an essential element of national security." Taiwan will allow integration to proceed only in profitable sectors. ${ }^{155}$ Professor Fleischauer argues, "as soon as this economic incentive is no longer given or superseded by national security concerns due to

\footnotetext{
${ }^{147}$ For comments on neofunctionalism, intergovernmentalism, and liberal intergovernmentalism, see Fleischauer, Fleischauer, supra note 142. Or Der-Chin Horng, The EU Model for a Taiwan-China Free Trade Agreement, 26 CHINESE (TAIWAN) Y.B. INT'L L. \& AFF. 35, 35-6 (2008) Or generally Frank Schimmelfennig, "Liberal Intergovernmentalism", in European Integration Theory (Antje Wiener \& Thomas Diez eds., 2004).

${ }^{148}$ Fleischauer, supra note 142, at 8-9

${ }^{149} I d$, at 11 .

${ }^{150}$ Such as the direct postal services and transportation links, see Fleischauer, supra note 142, at 10

${ }^{151}$ Ma Yingjeou identified three purposes and effects fo the ECFA and all are about economy. Mayingjiu: ECFA xian nongjiagou kan lanzi zhuang shenmeJ [Maying jiu: ECFA Structure Most Important], CAPTIAL, Mar. 2009, https://www.capital.com.tw/News/detial.app=12\&next1=1 \&ID=\%7BED70FB09-234F-4910-AA3B42D4CF012248\%7D\&num=J, last visited Jan 31, 2012. See also Chou, supra note 9, at 4.

152 "CEPA" stands for "Closer Economic Partnership Arrangement." It is an economic partnership agreement between Mainland China and Hong Kong, Macao, respectively. For its main contents, see www.wenzhouglasses.com/html/news/499016.html, last visited May 4, 2011.

${ }^{153}$ Cai, supra note 17 , at 2

${ }^{154}$ Fleischauer, supra note 142 , at $13-14$

${ }^{155}$ Id. at 14
} 
a shift in regional economic power, the integration dynamic will quickly wind down--or even be reversed."156 However, Taiwan has a heavy export-oriented economy and Mainland China is its No.1 exporting market. Mainland China allies with ASEAN to form a FTA, which triggered Taiwan to enter into an ECFA with Mainland China. This demonstrates that Taiwan's fear of isolation and losing competitiveness in the Mainland market still prevails over its concern of being absorbed by Mainland economy and "hollowing out" its key industries. Otherwise, the pan-blue Taiwan government led by Ma would not opt to "pro-China" ideology. Taiwan is fully aware of the shifting of regional economic power to Mainland China. This is shown by the diverse opinions debating whether Taiwan needed to conclude an ECFA with Mainland China. ${ }^{157}$ Nevertheless, thus far, Taiwan has not quickly winded down the economic integration process as the Intergovernmentalism and Liberal Intergovernmentalism suggested it should. Instead, the economic integration process will possibly speed up in Ma's second term. The reason is, if Taiwan would like to reject economic integration with Mainland China, it has to change its export-oriented economy, or find an alternative export market. This is certainly not easy.

The three leading integration theories are valuable; however when applying them to the cross-strait situation, we should note that they originally evolved in the post-war Western Europe $^{158}$ and may be hard to adapt to the Chinese situation for two reasons. First, the three theories have never explored integration between regions with disputes over sovereignty. ${ }^{159}$ Sovereignty is a contentious issue between Mainland China and Taiwan. Second, they have never even discussed the feasibility of integration between regions without political homogeneity. ${ }^{160}$ Mainland political system distinguishes from Taiwan's. ${ }^{161}$ The cross-strait situation is in sharp contrast to European member states where their political systems are similar. More importantly, American plays a big role in the cross-strait relation. However, in the European integration, US did not exert a significant influencing power.

It is still too early to predict whether the cross-strait BIA will promote political integration between Mainland China and Taiwan. However, it is sure that more economic exchange will help maintain a more peaceful Taiwan Strait. The BIA will certainly help bring stability and prosperity to the people of the Taiwan Strait. Peace and development are the hope of the people and should be the goal of the governments.

\footnotetext{
${ }^{156}$ Id. at 14

${ }^{157}$ Eg., Lu Zhen-Ru, Cross-strait Pact will Benefit PRC, not Taiwan, at http://www.taipeitimes.com/News/editorials/archives/2009/03/11/2003438171, last visited May 5, 2010.

${ }^{158}$ See Fleischauer, supra note 142, at 3.

${ }^{159} I d$. at 18. Within the EU, Turkey has a territorial dispute with the Republic of Cyprus, but it has never denied Cyprus' status as a sovereign state. Therefore, no extensive territorial dispute exists between EU member states.

${ }^{160}$ EU member states have generally recognize each other's democratic system. Copenhagen criteria require prospective EU member states should respect human rights, freedom of speech, the independence of the judiciary, and etc. See generally Desmond Dinan, Ever Closer Union: An Introduction to European Integration (3d ed. 2005).

${ }^{161}$ For Taiwan democracy, see Nuno Garoupa et al., Explaining Constitutional Review in New Democracies: The Case of Taiwan, 20 1, 1-40 (2011)
} 